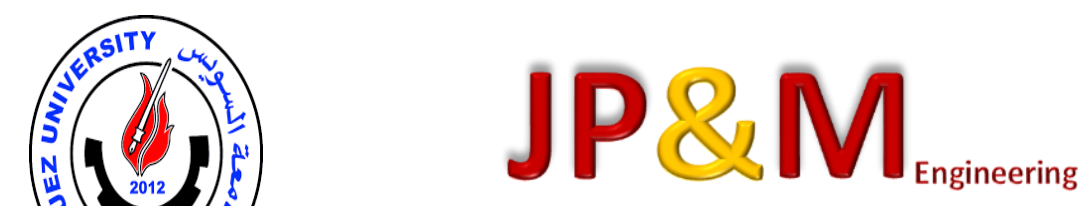

Journal of Petroleum and Mining Engineering

\title{
Utilization of stone column for improving seismic response of foundation on soft clay- Numerical study \\ Elsiragy, M. N.
}

Structural Engineering department, Faculty of Engineering ,6 October university - Egypt

Corresponding author e-mail: siragy2000@yahoo.com

\section{Article Info}

Received 19 Jan. 2021 Revised 28 Apr. 2021 Accepted 17 May 2021

\section{Keywords}

Soft clay, Stone column, PLAXIS 2D, Earthquake, Geotextile encasement

\begin{abstract}
Nowadays, some projects have to be constructed in areas having thick layers of soft clay. These soft soils with low shear strength and high voids ratio, lead to excessive settlements even if subjected to low vertical or lateral loads. For this reason, soft clays are considered problematic soils for foundation purposes. Several improvement techniques have been done to enhance such clay. Stone columns have been used to improve soft soils by increasing its carrying capacity and reducing the settlement. In this paper, a numerical study on seismic behavior of stone column in soft clay subjected to earthquake loading has been performed. A two-dimensional plane strain program PLAXIS (dynamic version) is used for the present numerical modeling. A series of modeled stone columns were simulated with different diameters and spacing between columns. Also, the influence of geotextile encasement on the performance of stone columns, foundation systems in soft clay is investigated and compared with the behavior of ordinary stone columns without casing. The results showed that the ordinary stone column with small spacing and larger diameter has a greater bearing capacity and give a smaller settlement, compared to the column with large spacing. In addition, the geotextile encasement for stone column can be provided a significant increase in stone column capacity as well as a huge reduction in settlement is considered with increasing the encasement strength.
\end{abstract}

\section{Introduction}

Stone column technique is considered to be one of the finest soil improvement techniques and it's been used wide over the last thirty years in several countries round the world as a ground improvement methodology (Black et al. 2007). Soil stabilization by the stone column methodology overcomes the settlement drawback and low stability. Another advantage of the stone column methodology is that the simplicity of its construction (Isaac and Girish 2009). enclosure of the stone column with geosynthetics is one amongst the stone column reinforcement ways. The Geosynthetic sheathed stone columns have variety of benefits as a soil improvement technique such as being stiffer, stronger and has a lot of resistant than normal stone column. Many researchers dispensed completely different studies to grasp the behavior of stone columns in several conditions. These studies square measure field, laboratory, and numerical studies. Moayed, et al. and Vikunj (2017), studied numerically the behavior of 2 differing types of stone columns sheathed and un-encased column at completely different traditional pressure, the result of column diameter in 2 cases is taken into account, they found that by increasing the traditional pressure and diameter of stone column the shear strength of soil increased based on the theory of increasing the densification of the stone column leads to increase of modulus of elasticity and the more larger diameter the more densification occur. Sakr, et al (2017), dispensed a numerical modeling of stone columns in soft clay for drained and undrained conditions victimization PLAXIS second software system.

The results showed that reinforcing soft clay by stone columns having (L/D) ratios "where $L$ is the stone column length and $D$ is the diameter of the stone column" between two to eight increase the load-carrying capability of the clay, additionally, a comparison between the results of drained and undrained analysis showed reasonable results as will be stated. The pore water pressure among the stone columns just in case of undrained condition will sustain concerning twelve to twenty fifth of the last word load in drained condition reckoning on dimensions of the stone column and shear strength of the clay. Reddy, and Mohanty (2017), studied seismic behavior of sloping bedded soil with and while not stone column, they over that in earthquake loading, the pore water pressure within the soil deposit gets raised and therefore the presence of stone column helps in dissipating the developed pore water pressure. Also, it acts as a reinforcing material in soil deposits. The check result shows that the stone column improved ground reduces the surplus pore pressure, acceleration and deformations a lot of compared to the unimproved ground. Fathi, and 
Mohtasham, and Demir, and Sarici (2016), conferred a numerical study on the influence of geosynthetic enclosure on the behavior of stone column in soft clay. PLAXIS software system has been used for this study, from results they found that load carrying capability and bulging behavior of geosynthetic sheathed stone column was considerably influenced by the depth and stiffness of enclosure. Keykhosropur, et al. (2011), dispensed a comparative study between the behavior of the normal and geosynthetic sheathed stone columns (GEC's). Also, constant studies and analyses square measure dispensed to research the consequences of parameters like stiffness and length of the geosynthetics also as modulus of physical property of the column's material on the mechanical behavior of the cluster of GEC's. The results indicate that increasing the stiffness of the enclosure clearly enhances the behavior of the cluster of GEC's. The results additionally showed that the performance of the GEC's is relatively less sensitive to values of internal friction and modulus of physical property of the column's materials.

Based on geotechnical studies, it has been found that the investigation of seismic behavior of foundation on stone column are limited therefore, in this paper, two-dimensional plain strain program PLAXIS (dynamic version) is used to study the seismic behavior of encased and un-encased stone column in soft clay during earthquakes. Parametric analysis is also done to evaluate.

\section{Numerical modeling and selection of parameters}

The plane strain model was used with the six-node element. For the mesh generation, the worldwide coarseness is about to 'coarse' and therefore the clusters within the building square measure refined double (increasing the mesh refinement increases the generated mesh accuracy). This is often attributable to the high concentration of stresses that may be expected simply in and underneath the building components. The undersoil consists of 2 layers, the primary a soft clay layer with a fifteen $m$ thickness, and therefore the second may be a sand layer with a $25 \mathrm{~m}$ thickness. The 2 soils square measure assumed to be Mohr-Coulomb in dynamic analysis. Properties of used soil square measure conferred in table (1). The material properties used in the paper are within the normal ranges of the soils from previous researches. In dynamic calculation the Raleigh damping (the damping factors of the soil for the dynamic analysis in PLAXIS) is taken into account at vertical boundaries and with $(\alpha, \beta=0.01$, this value choosed after some trials by PLAXIS) so as to resist the Lord Rayleigh waves. While the plastic properties of soil (viscous properties) are defined by using material damping, which is defined in Plaxis by Rayleigh ( $\alpha$ and $\beta$ ), where a damping term is assumed which is proportional to the mass and stiffness of the system (Rayleigh damping) such that: $C=\alpha M+\beta M, C$ damping coefficient, $M$ mass, $K$ stiffness and. ( $\alpha$ and $\beta$ ) Rayleigh coefficient. The Rayleigh damping is considered to be object-dependent in the material data set to consider the plastic properties of soil during the dynamic analysis in Plaxis. The groundwater table is assumed at $3 \mathrm{~m}$ below the ground surface to consider the excess pore water pressure so the soil material is assumed to be undrained. The adopted building consists of a basement and 10 floors with a total height of 33 meters; it has two bays with a total width of 10 meters. The building and foundation are simulated as plate properties (using plate properties achieve better correlation for the substructure simulation), Beam elements of elastic material. The floor and wall plate properties are $(E A=2.344 \times 107$ $\mathrm{kN} / \mathrm{m}, \mathrm{El}=3.288 \times 105 \mathrm{kN} / \mathrm{m} 2 / \mathrm{m}$ with weight of 17.5 $\mathrm{kN} / \mathrm{m} / \mathrm{m}$ and Poisson's ratio $v=0.15$ ). The building foundation is assumed a reinforced concrete raft, is modeled as an elastic beam element, the raft is $1 \mathrm{~m}$ thickness its plate properties are $(E A=2.2 \times 107 \mathrm{kN} / \mathrm{m}$ and $\mathrm{EI}=1.833 \times 106 \mathrm{kN} / \mathrm{m} 2 / \mathrm{m}$ with weight of 25 $\mathrm{KN} / \mathrm{m} / \mathrm{m}$ and Poisson's ratio $=0.15)$.

The building foundation is assumed a reinforced concrete raft, is modeled as an elastic beam element, the raft is $1 \mathrm{~m}$ thickness its plate properties are (EA = $2.2 \times 107 \mathrm{kN} / \mathrm{m}$ and $\mathrm{EI}=1.833 \times 106 \mathrm{kN} / \mathrm{m} 2 / \mathrm{m}$ with weight of $25 \mathrm{KN} / \mathrm{m} / \mathrm{m}$ and Poisson's ratio $=0.15$ ). Geosynthetic material as geotextile of polypropylene (PP) is used as encasement material. For all the models analyzed, the values of S/D was taken as $1,2,3,4$ where $S$ is the spacing between columns and $D$ is the column diameter and was varied from $0.5 \mathrm{~m}$ to $1 \mathrm{~m}$. Numerical modeling was done using two different earthquakes first New Mexico earthquake with magnitude $=5$ Richter, and the second Elcentro earthquake with magnitude $=6.9$ Richter. The geotextile tensile strength was varied from (2000, $3500,6500 \mathrm{KN} / \mathrm{m}$ ) (the most used tensile strength values are based on the field experience). The earthquake is sculptured by imposing a prescribed horizontal displacement at rock bottom of the boundary in distinction to plain unit length $(U x=$ zero.01m and $U y=0$ ) as utilized in manual default. The pure mathematics of the finite part model adopted for the analysis is shown in Figure 1.

The stone column simulated the properties of piles in the (2D PLAXIS) model respectively. The spaced piles in the long direction were converted using the following equation to an equivalent wall in the $2 \mathrm{D}$ analysis. Idealization of stone columns in-plane strain where stone column spacing S, D is the stone column diameter and $\mathrm{t}$ is equivalent strip as discussed by Zahmatkesh and Choobbasti, 2010.

$$
\pi^{*} \mathrm{D} 2 / 4 \text { = Spacing * } \mathrm{t} \text { equivalent }
$$

Table 1 Properties of soil used in numerical analysis

\begin{tabular}{|c|c|c|c|c|c|c|c|}
\hline \multirow{2}{*}{$\begin{array}{l}\text { Type } \\
\text { of soil }\end{array}$} & \multicolumn{2}{|c|}{$\begin{array}{l}\text { Unit weight } \\
\mathrm{kN} / \mathrm{m} 3\end{array}$} & \multicolumn{3}{|c|}{$\begin{array}{c}\text { Shear } \\
\text { strength } \\
\text { parameters }\end{array}$} & \multicolumn{2}{|c|}{$\begin{array}{c}\text { Soil stiffness } \\
\text { parameters }\end{array}$} \\
\hline & dry & lat sat & C & $\phi$ & $\psi$ & $E$ & $Y$ \\
\hline $\begin{array}{l}\text { Soft } \\
\text { clay }\end{array}$ & 15.56 & 19.45 & 30 & 0 & 0 & 5500 & 0.45 \\
\hline $\begin{array}{l}\text { Dense } \\
\text { sand }\end{array}$ & 18 & 20 & --- & 38 & 8 & 40000 & 0.35 \\
\hline
\end{tabular}




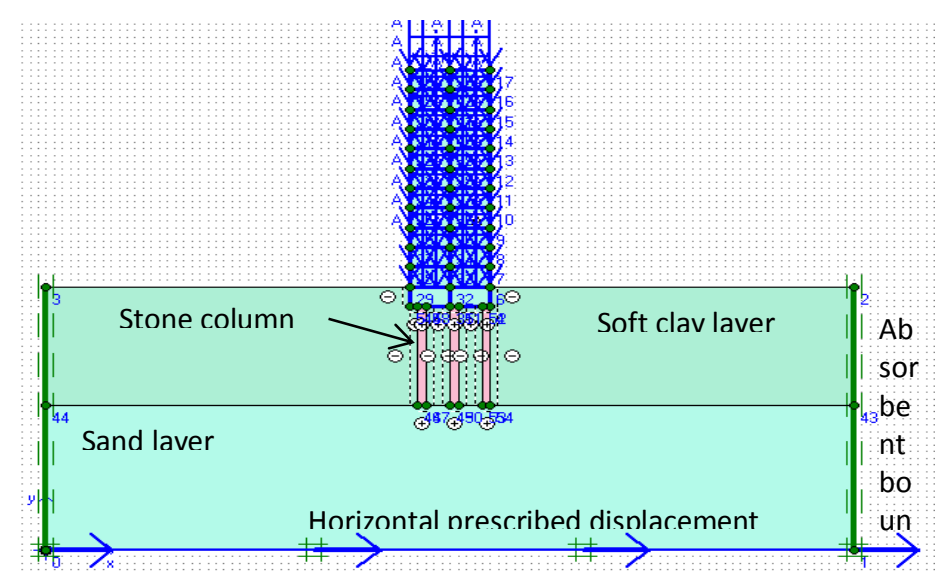

Figure 1 Geometry model with standard earthquake boundary conditions

\section{Analysis procedures}

An arrangement of energetic numerical models was run for the issue beneath examination utilizing distinctive values of column distance across and diverse $S / D$ values. The calculation strategy includes two-phase. The primary one could be a normal plastic calculation in which the building is built. The moment may be an energetic investigation in which the seismic tremor is mimicked. In this stage, the uprooting is reset to zero and the time interim $10 \mathrm{sec}$, the increasing speed of the input seismic tremor is chosen from the default increasing speed information record in program SMC record (Solid Movement CD-ROM). The increasing speed time history utilized for Unused Mexico and El-Centro seismic tremor with size 5 and 6.9 individually. Sometime recently the work era, the water weight can be enacted for considering the pore water weight.

\section{Program validation or verification}

The study was carried out using an available finite element method to compare the load-settlement behavior with the model test results and for relevant laboratory test results. The adopted finite element program Plaxis was validated by analyzing the load settlement behavior of stone columns in a model test that was investigated by Ambily and Gandhi (2007). In this investigation, soft clay and stone column is modeled using the Mohr-Coulomb criterion (linear elastic). To start with, the model developed in finite element program considering elastic-plastic response is compared with this similar study.

The model investigated by Ambily and Gandhi (2007) provides the behavior of inside columns among a large group of columns. Here, the interior column was idealized as a unit cell. The study is considered the stone column and surrounding soil loaded together. The modeling of drained behavior is considered for all input elements like clay, stone column, and sand. The unit cell is modeled model by applying initial stresses in all materials using the KO method. Load is applied as prescribed displacement to provide equal vertical strain conditions. Also, the Fine meshes that are generated using 15-noded triangular elements and boundary conditions for the analysis are considered. Radial deformation is restricted but vertical deformation is allowed along the horizontal. It can be

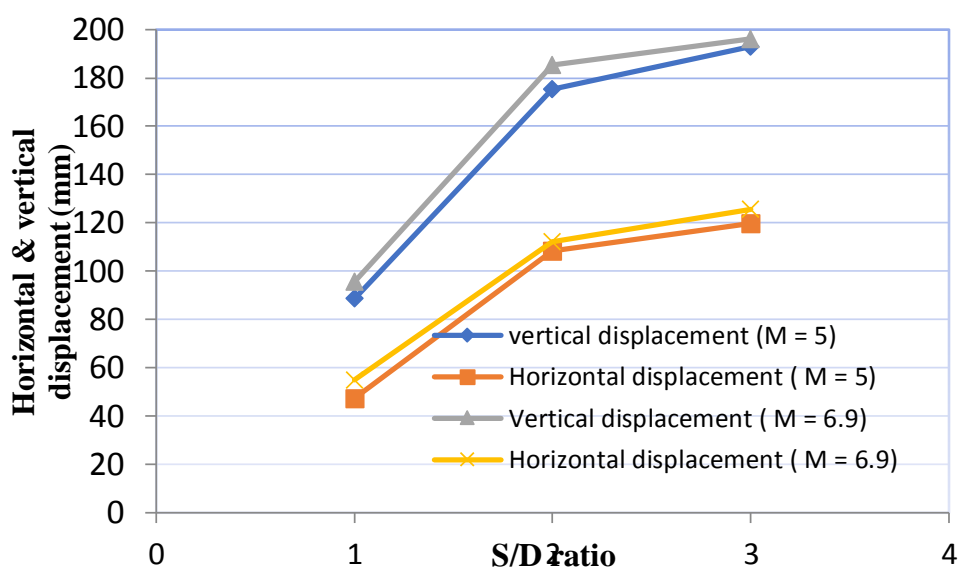

Figure 2 Comparison between horizontal \& vertical displacement and S/D ratio at constant diameter $(D)=1 \mathrm{~m}$

also suggested that no interface element is used in analysis.

According to the axial stress developed at the stone top and settlement behavior, for the case of entire loaded area, the axial loaded versus settlement behavior from numerical analysis reported by Ambily and Gandhi, (2007) and Finite element model.

The results from the introduced analysis agree well with the results obtained by Ambily and Gandhi, (2007). Therefore, the plaxis $2 \mathrm{~d}$ program can be used to study the current problem under investigation in the form of the dynamic module as structure subjected to an earthquake resting on stone column within the soft clay layer.

5. Results and analysis

5.1. Effect of stone column spacing

For the current research, it has been found that in case of the system subjected to EL- Centro earthquake ( $M=6.9$ ), the bearing capacity of soft clay increased and settlement decrease with using stone column with small spacing (small S/D ratio) the lateral deformation decreased from $121 \mathrm{~mm}$ at $S / D=3$ to 56 $\mathrm{mm}$ at $\mathrm{S} / \mathrm{D}=1$. This referred to the lateral deformation is reduced by as much as $46.3 \%$ where $S / D$ varied from 3 to 1 as illustrated in figure 3 . Also, the settlement was 193.3 at $S / D=3$, and then it decreased to 88.58 at $S / D=1$, the reduction was reached to $47 \%$ as shown in fig. 2 . In addition, figure 3 presented a comparison between the lateral and vertical displacement during El-Centro and New Mexico earthquakes.

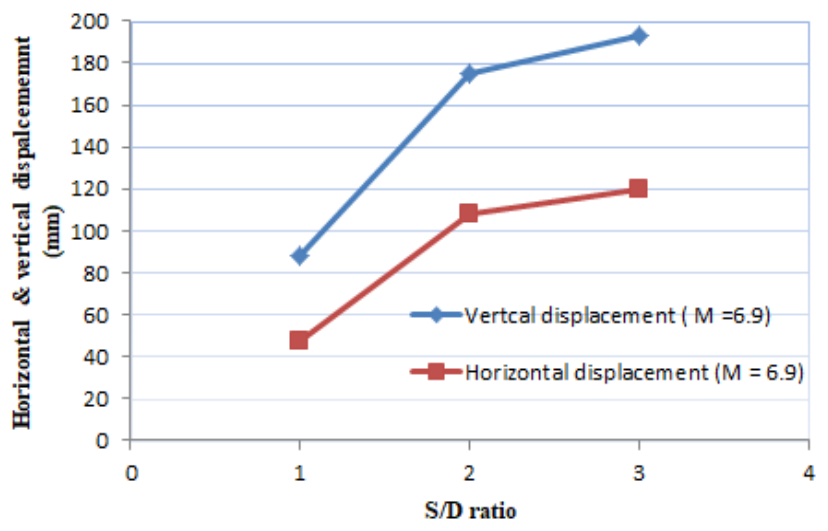

Figure 3 Relationship between horizontal \& vertical displacement and S/D ratio at constant diameter $(D)=1 \mathrm{~m}$ 
Figure 4, presented the reduction of foundation horizontal and vertical displacement. It has been found that the foundation settlement decreased with decreasing S/D due to increasing the soil bearing capacity in this case, the settlement decreased from $93.3 \mathrm{~mm}$ to $50.3 \mathrm{~mm}$ where S/D varied from 3 to 1 . Also, the foundation lateral displacement decreased from $78.6 \mathrm{~mm}$ to $38.3 \mathrm{~mm}$ with a reduction ratio where S/D varied from 3 to 1.

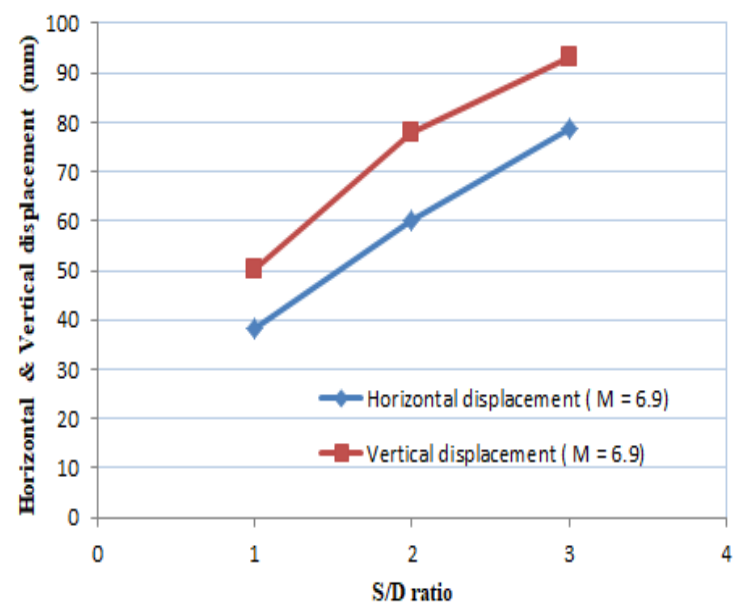

Figure 4 Relationship between horizontal \& vertical displacement and S/D ratio at constant diameter $(D)=1 \mathrm{~m}$ at foundation level during El-Centro earthquake $(M=6.9)$

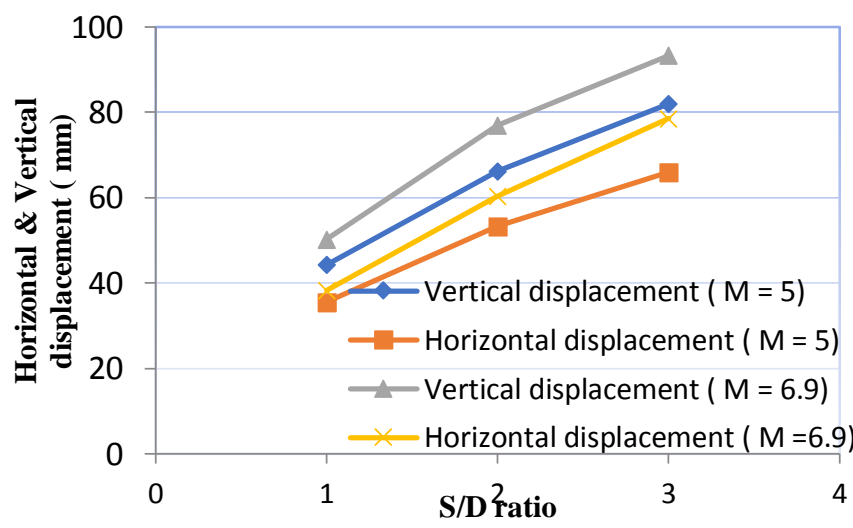

Figure 5 Comparison between horizontal \& vertical displacement and S/D ratio at constant diameter $(D)=1 \mathrm{~m}$ at foundation level during New Mexico earthquake $(M=5)$, and $\mathrm{El}$-Centro earthquake $(\mathrm{M}=6.9)$

\subsection{Effect of stone column diameter}

A series of numerical models were studied with different stone column diameters of $0.5,0.8$, and $1 \mathrm{~m}$. it was found that increasing the column diameter and decreasing the distance between columns give a large bearing capacity. This is maybe because with increasing the column diameter the column strength increased too as a result the bearing capacity increased, and the settlement decreased. Figure 6illustrates the relation between settlement and different values of column diameter. It is obvious that settlement decreased with increasing column diameter. The settlement was 90.5 at $D$ $=0.5$ and decreased to 61.3 with a reduction ratio of 66 $\%$ when increasing column diameter from $0.5 \mathrm{~m}$ to $1 \mathrm{~m}$.

In addition, the horizontal displacement decreased with increasing the column diameter. At $D=1 \mathrm{~m}$ lateral displacement was reached to 93.6 , and decreased to 56.2 at $D=0.5 \mathrm{~m}$. It is obvious that the settlement and lateral displacement decreased with increasing the column diameter at constant S/D value. This confirmed that stone columns with larger diameters have a greater bearing capacity andsmaller settlement due to increasing the column size and strength.

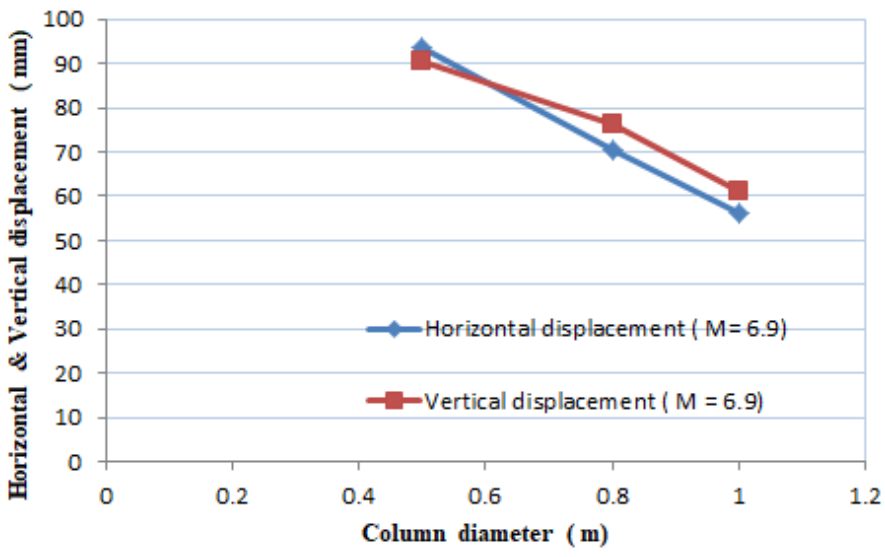

Figure 6 Relationship between horizontal \& vertical displacement and column diameter at constant S/D ratio during El-Centro earthquake $(M=6.9)$

Moreover, increasing the column diameter has a great effect on enhancing the foundation bearing capacity and settlement during varied seismic loads. The foundation settlement during the El-Centro earthquake decreased from $86.7 \mathrm{~mm}$ to $43.2 \mathrm{~mm}$ with a reduction ratio of $49.83 \%$ when increasing the column diameter from $0.5 \mathrm{~m}$ to $1 \mathrm{~m}$. Also, the lateral displacement of the foundation decreased from 78.9 $\mathrm{mm}$ to $44.5 \mathrm{~mm}$ where column diameter varied from 0.5 to $1 \mathrm{~m}$. The reduction ratio reached $56.4 \%$ as illustrated in fig.7. Also fig.7 compared the reduction ratio of lateral and vertical displacement at foundation level during EL-Centro and New Mexico earthquake.

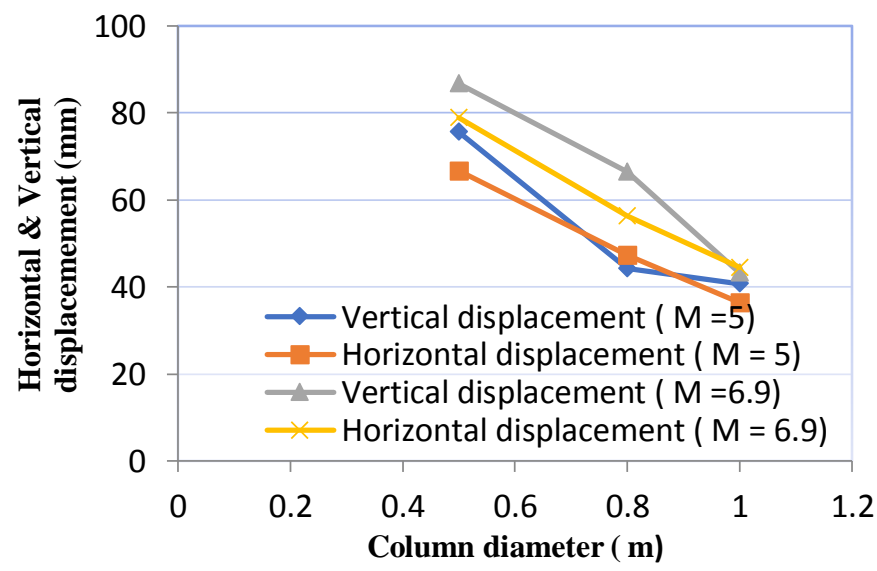

Figure 7 Relationship between horizontal \& vertical displacement and column diameter at foundation level 


\subsection{Effect of increasing encasement tensile strength:}

Increasing the tensile strength of geotextile encasement makes stone columns stiffer and consequently under a constant load, tension force generated in the encasement and lateral confinement provided by it increase. Therefore, the maximum lateral deformation for the soil around the reinforced zone decreased from $40 \mathrm{~mm}$ to $24 \mathrm{~mm}$ with a decreasing ratio of $60 \%$, and within the confinement zone, the deformation decreased from 20 to 12 at $E A=2000 \mathrm{kN} / \mathrm{m}$ and 6500 $\mathrm{kN} / \mathrm{m}$ respectively as illustrated in Figures 8. Also, settlement of encased stone column decreases from 53.5 to 35 with a decreasing ratio of $66 \%$ at $E A=2000 \mathrm{kN} / \mathrm{m}$ and $6500 \mathrm{kN} / \mathrm{m}$ respectively as shown in Figures 8 .

In addition, settlement and lateral deformation decreased from 88.58 and 50 in the case of using unencased stone column respectively to 35 and 24 in case of using encased stone column with tensile strength 6500 $\mathrm{kN} / \mathrm{m}$. A comparison between settlement values during different earthquakes when using encased and unencased stone column at constant diameter $D=1 \mathrm{~m}$, and different S/D ratios is illustrated in Figure 9.

Moreover, Figure 10 presented a comparison between the reduction ratio of lateral and vertical displacement at the foundation level with increasing the encasement tensile strength.

The foundation settlement decreased from 77.3 to $45.5 \mathrm{~mm}$ with increasing the encasement strength from 2000 to $6500 \mathrm{kN} / \mathrm{m}$. Moreover, the lateral deformation decreased from 88.7 to $53.1 \mathrm{~mm}$ with a reduction ratio of $59.86 \%$. this reduction in both vertical and horizontal displacement at foundation level may be referred to that using the geotextile encasement increasing the column stiffness, as a result, the soil bearing capacity under the foundation increased consequently the foundation settlement and deformation decreased.

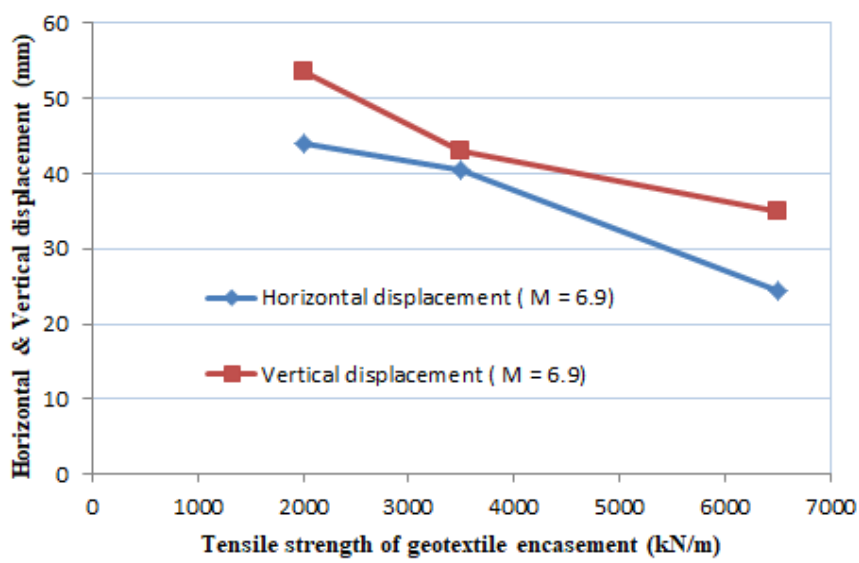

Figure 8 Reduction of horizontal \& vertical displacement for soil between columns with increasing geotextile encasement tensile strength during El-Centro earthquake $(M=6.9)$

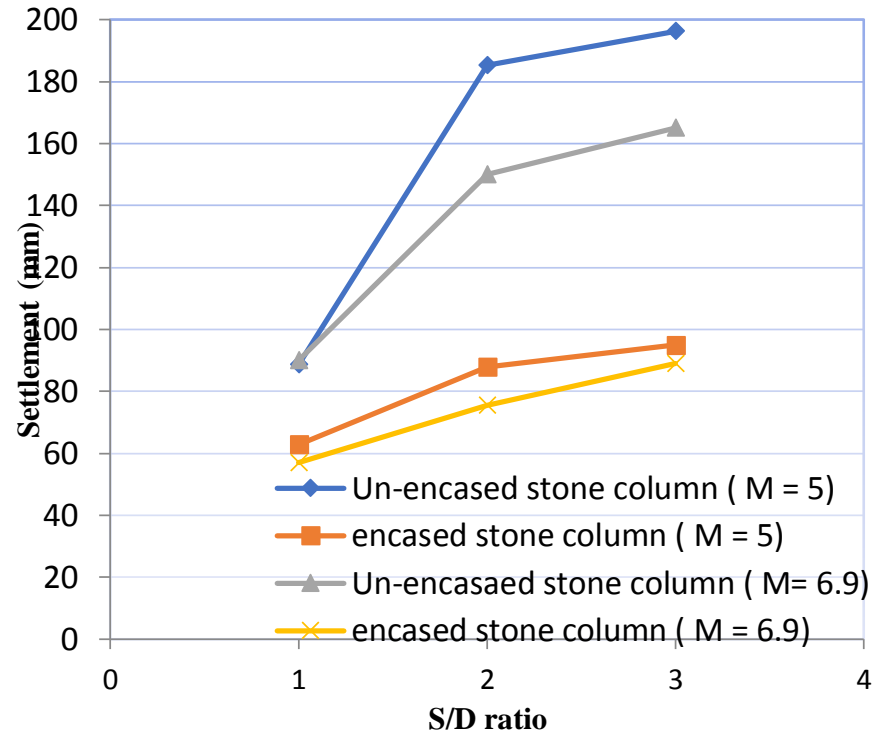

Figure 9 Relationship between settlement and S/D ratio for encased and un-encased stone column at constant $D=1 \mathrm{~m}$ at

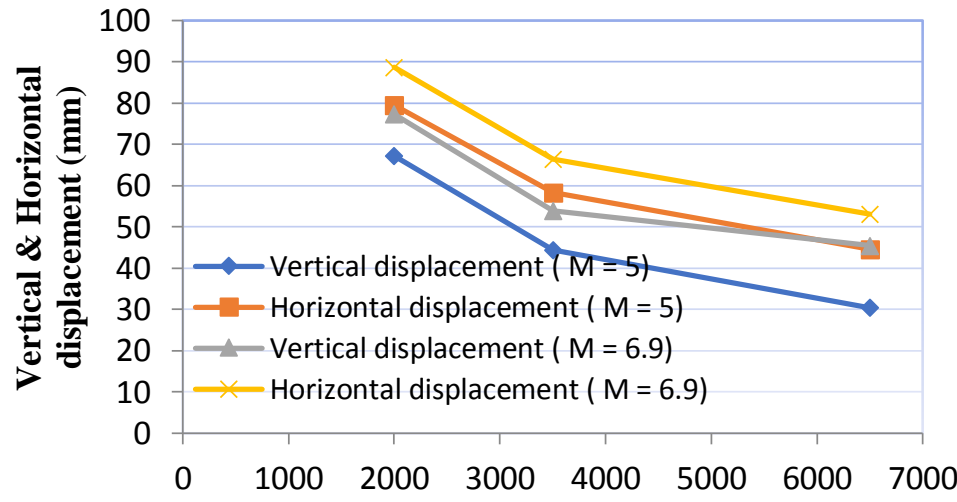

Tensile strength of geotextile encasement $(\mathrm{kN} / \mathrm{m})$

Figure 10 Reduction of horizontal \& vertical displacement with increasing geotextile encasement tensile strength at foundation level during New Mexico earthquake ( $M=5)$, and 


\section{Conclusion}

Stone column is a good soil improvement technique which increases the soft soil bearing capacity and decrease settlement during earthquake it also increases the soil shear strength due to the confinement effect and decreasing the amount of pore water pressure in the soil mass.

The existence of stone column in soft soil under foundation decreasing lateral and vertical displacement during earthquake (Using PLAXIS 2D allow measuring the soil particles displacement in 2 ways and it is found that a decrease in displacement due to the stone column existence prevent the propagated waves to affect on soil particles) during earthquake, the foundation displacement decreased from 32.39 at $S / D=3$ to 1.12 at $S / D=1$ when using a group of stone columns with a diameter of $1 \mathrm{~m}$.

Stone column that surround by weak soil such as soft clay will bulge more since lateral confinement to hold soil is less (soft clay around the stone column affect negatively in its efficacy so the number of the stone columns and the spacing between them should be investigated sperately). Further improvement can be done by reinforcing the column with geothynsetic materials to increase its axial load carrying capacity and minimize bulging.

To improve the load-bearing capacity and decrease settlement of soft soil and stone column by increasing the geothynsetic tensile strength. The reduction of settlement reached to $66 \%$ when increasing the tensile strength from 2000 to 6500 $\mathrm{kN} / \mathrm{m}$.

Stone columns with narrower spacing distances and large diameters have a greater bearing capacity and smaller settlement than wider spacing and small diameters of stone columns.

- $\quad$ The reduction of settlement reached $80 \%$ when increasing the column diameter from $0.5 \mathrm{~m}$ to $1 \mathrm{~m}$ (this range of diameters achieve the optimum results with respect to economical view and an accepted improvement percentage while the diameter is less than $0.5 \mathrm{~m}$ slightly make difference on settlement values, on the other hand increasing the diameter than $1 \mathrm{~m}$ will increase the cost of the improving process compared to the quested settlement reduction value.)

\section{Conflicts of interest}

There are no conflicts to declare.

\section{References}

[1] R. Ziaie Moayed, M. Hossein Zade, "Numerical Analysis of Geosynthetic- Encased Stone Columns under Laterally Loads", International Journal of Civil and Environmental Engineering Vol:11, No:1, 2017.

[2] Ambily, A.P., Gandhi S.R., "Behavior of stone columns based on experimental and FEM", Journal of Geotechnical and Geoenvironmental Engineering, Vol. 133, pp. 405-41, 2007.
[3] C. Cengiz, E. Güler, "Seismic behaviour of geosynthetic encased columns and ordinary stone columns", Geotextiles and Geomembranes, Pp. 40:51, 2017.

[4] C.S.Reddy, and S.Mohanty, "Seismic behaviour of stone column on a sloping layered soil", Sixth Indian Young Geotechnical Engineers Conference 6IYGEC2017, Pp. 1:4, 2017.

[5] E. Fathi, and R. Mohtasham, "Numerical Analysis of the Reinforced Stone Column by Geosynthetic on Stability of Embankment", World Congress on Civil, Structural, and Environmental Engineering (CSEE'16), No: ICGRE 112, 2016. [6] M. Sakr, M. Shahin, A. Farouk and K. Moneim, "Numerical Modeling of Stone Columns in Soft Clay for Drained and Undrained Conditions", Electronic Journal of Geotechnical Engineering, Vol.22, Pp.1907:1924, 2016

[7] A.Demir, and T.Sarici, "Bearing capacity and bulging behavior of geogrid encased stone columns", SUJEST, V4, S2, 2016.

[8] M. Jiang, S.Han and H. LI, "Numerical Study of Stone Column Reinforced Composite Foundation of Highway under Static and Seismic Load", Advanced Materials Research Vols. 602-604, 2013.

[9] A. Marto, R.Moradi, F.Helmi, N.Latifi, and M.Oghabi, "Performance Analysis of Reinforced Stone Columns Using Finite Element Method" , Electronic Journal of Geotechnical Engineering, Vol.18, Pp.315:323, 2013.

[10] L. Keykhosropur, A. Soroush and R. Imam, "A Study on the Behavior of a Geosynthetic Encased Stone Column Group Using 3D Numerical Analyses" Pan-Am CGS, Geotechnical conference, 2011.

[11] M. Elsawy, K. Lesny, and W. Richwien, "Behavior of ordinary and encased stone columns studied by FEM analysis", 17th International Conference on Soil Mechanics and Geotechnical Engineering, Pp. 2350:2353, 2009.

[12] Zahmatkesh A., Choobbasti.J., "Settlement evaluation of soft clay reinforced by stone columns, considering the effect of soil compaction", International Journal of Recent Research and Applied Studies (IJRRAS), Vol. 2, pp. 159-166, 2010. 